\title{
AUSTRALIAN
}

JOURNAL

OF

\section{GUIDANCE AND \\ COUNSELLING}

\section{VOLUME 6 NUMBER 1}

NOVEMBER 1996

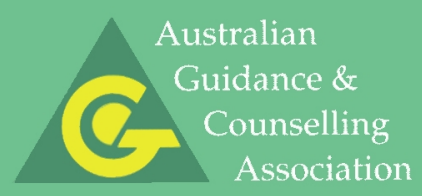




\section{Australian Journal of Guidance \& Counselling}

\section{Editor}

Ivan Watson, Senior Guidance Officer, Waverley District, Victoria

\section{Associate Editor}

Paul Burnett, Senior Lecturer, Queensland University of Technology

\section{Editorial Panel}

Gabrielle Elich, Guidance Officer, Queensland

Greg Field, Guidance Officer New South Wales

Greg Henderson, Guidance Officer, Victoria

Robynne Moore, Guidance Officer, Victoria

\section{Australian Guidance \& Counselling Association Limited 1995/96}

\section{Executive Members}

$\begin{array}{ll}\text { President } & \text { Jan Wilson } \\ \text { Secretary } & \text { Pauline Glascow } \\ \text { Treasurer } & \text { Royce Herbert } \\ \text { Membership Secretary } & \text { Kate Prescott } \\ \text { Newsletter Editor } & \text { Robyn Gillies } \\ \text { Immediate Past President } & \text { Kate Prescott } \\ \text { Journal Editor } & \text { Ivan Watson }\end{array}$

\section{State Representatives}

$\begin{array}{ll}\text { New South Wales } & \text { Ruth Still } \\ \text { Victoria } & \text { Ivan Watson } \\ \text { Queensland } & \text { Lorraine Wallis } \\ \text { South Australia } & \text { Clive Budden } \\ \text { Tasmania } & \text { Philip Doyle } \\ \text { Western Australia } & \text { Grant Walsh } \\ \text { Northern Territory } & \text { Ken Fitzgerald } \\ \text { Australian Capital Territory } & \text { Carolyn Sullivan }\end{array}$

The Australian Journal of Guidance and Counselling presents articles of relevance to all areas of guidance and counselling. Papers may address theoretical, practical or training issues, and may focus on educational or psychological topics.

Subscriptions: The Journal is published annually. Subscriptions rates are AGCA members - $\$ 10$ (included in annual membership fee); Individuals (non-AGCA members) - \$15; Institutions $-\$ 20$.

Requests for subscriptions and back numbers should be sent to:

Australian Journal of Guidance \& Counselling

12 Croydon Road

SURREY HILLS VIC 3127 


\section{AUSTRALIAN JOURNAL \\ $\mathrm{OF}$ \\ GUIDANCE \& COUNSELLING}

Volume 6 Number 1 November 1996

\section{Contents}

iii Editorial

\section{Professional Issues}

1 Supervision for school counsellors: when will we get what we really need?

John Barletta

9 Perceptions of guidance officers and senior guidance officers about clinical supervision: a preliminary study Mary McMahon and John Solas

$21 \quad$ Guidance on the Internet

Peter Hallinan

31 School counsellors' responses to homosexuality and to lesbian and gay students

Adriana Fallone and Daphne Hewson

\section{Research Papers}

Does social anxiety increase with age?

Marilyn Anne Campbell

Promoting cooperative behaviours in student work groups Robyn Gillies

61 Evaluation of the Sheidow Park social problem solving program for primary school children: a field study Jordana Bayer, Rosalyn Shute and Colin MacMullin 
73 School experience of adolescents with chronic fatigue syndrome Evelyn Spratt and Daphne Hewson

87 The coping strategies used by adolescents in intact and in separated families

Erica Frydenberg and Ramon Lewis

\section{Articles}

99 Social phobia in children and adolescents: assessment and treatment

Neville King, Chris Madden and Bruce Tonge

107 Reasons for truancy: a literature review for school counsellors Richard Haddon

115 Eating disorders: prevention and recovery reflections on two research projects

Catherine Garrett

125 An overview of developmental issues in counselling adoptive families

Juliet Harper

\section{Reviews}

133 Instructional Methods for Adolescents with Learning and Behavior Problems (2nd ed.)

Peter Hallinan and Pam Hallinan

134 Seven Keys to Successful Study (2nd ed.)

Richard Haddon

135 Split Ends: Teenage Stepchildren

Dr Wendy Patton

135 Happy Children

John Barletta

136 The Wide Range Assessment of Memory and Learning Kylie Wolstencroft

137 Bullying in Schools and What to do About it Ivan Watson 